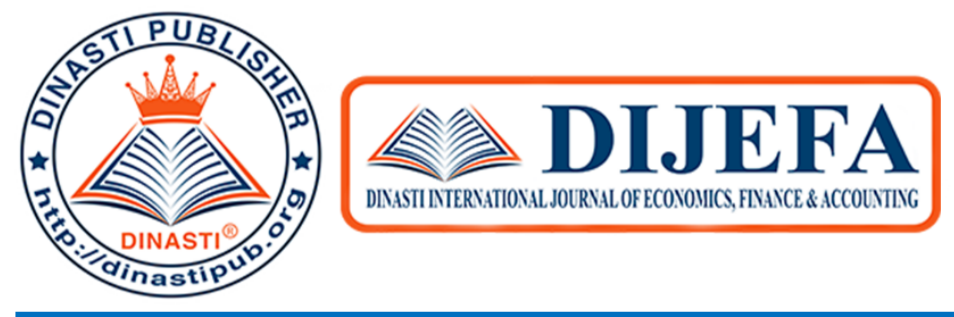

+6281387654578?

+6281387654578@

https://dinastipub.org/DIJEFA (-)

dinasti-info@gmail.com (†)

\title{
DYNAMIC SUPPLY RESPONSE : IMPLICATIONS FOR INDONESIA SOYBEAN CROP
}

\author{
Edison $^{1}$, Dharia Renate ${ }^{2}$, Denny Denmar ${ }^{3}$ \\ ${ }^{1}$ University of Jambi, Indonesia. \\ ${ }^{2}$ University of Jambi, Indonesia. \\ ${ }^{3}$ University of Jambi, Indonesia.
}

\begin{tabular}{|c|l|}
\hline $\begin{array}{c}\text { ARTICLE INFORMATION } \\
\text { Received: 13 July 2020 } \\
\text { Revised: 15 August 2020 } \\
\text { Issued: 24 September 2020 }\end{array}$ & $\begin{array}{l}\text { Abstract: The purpose of the study is to explore the } \\
\text { supply response model of the soybean crop in terms of } \\
\text { alternative specifications also implications economics. } \\
\text { To apply model, considerations through the availability } \\
\text { of production lags concept also the existence of } \\
\text { expected price and gross revenue because of producer's } \\
\text { response explanatory preference on movement } \\
\text { economic situation. The results showed that the existing } \\
\text { lags were due mostly to the problems also quick } \\
\text { adjustment expenditure rather than correcting expected } \\
\text { author }\end{array}$ \\
$\begin{array}{l}\text { E-mail: } \\
\text { dhariarenate@yahoo.com } \\
\text { dennydenmar101264@gmail.c quantitative result was the same as gross } \\
\text { availability of economic decisions. Meanwhile, } \\
\text { elasticities price found through the model response } \\
\text { specification tended around a fourth of the model } \\
\text { applying price specification. The model response } \\
\text { specification produced more explanation in terms of } \\
\text { production also elasticity of input expenditure. }\end{array}$ \\
Keywords: Dynamic Supply response, Production \\
response, and Soybean crop
\end{tabular}

\section{INTRODUCTION}

The agricultural sector has to play a crucial role in Indonesia's economic development, where primarily exists an important change in food self- sufficiency also improving food markets nowadays. Efforts toward diversifying economic base through agriculture, increased revenue through money valuating also supporting to nation's gross domestic product has to evaluate a balanced food supply response characters through the price policy program also another non-price component of food yield. Considering of agricultural supply response on view policy also market characteristics and also planting seasonal is not quickly, but continuous a time-lapse called lag (Gujarati and Porter, 2009). Such lags offer enough time for decisions that accentuate food accessibility and food security (Tollens, 1998). The past 
food policy framework in Indonesia failed to tackle food insecurity because it mainly focused on agricultural productivity improvement such as the correct meaning of food selfsufficiency, employment era, foreign value earnings also poverty reduction (Bappeda, 2018; Edison, 2020). No empirical study has linked the productivity growth of soybean to settle accessibility such considering its real output longtime especially deals with agricultural supply response.

Soybean (Glycine max) supply will assume steady accessibility if and only if the planned (expected) supply, from a planned demand required for healthy living, meets the actual supply over some time. Incessant shortages or surpluses arising from reallocation of both price and non-price factors invoke supply instabilities and deviation from the planned supply. Soybean supply in Indonesia is unstable. There is a domestic annual supply shortfall of about 100,000 tons for soybean meal and 300,000 tons for vegetable oil. The supply increased by only 2,600 tones/farmer in the late ' 60 s but dropped by $18.6 \%$ following farm resource reallocation along the oil boom season in the '70s (Tripath, 2008). It rose again by 9.11\% annually from 1984 to 160,000 metric tons in 1995 and later to 550,000 metric tons in 2014, leaving a national demand gap of 200,000 metric tons that must be met through importation.

Agriculture sector still plays a crucial role in Indonesian development such as supporting to GDP, money value-added also the labor sector. The agriculture sector had almost forgotten until 1986's since development was considered to be the same as the industrialization sector. This statement was supported by the thing that the industry sector is the crucial sector, while the agriculture sector is the usual sector also does not have an impact on incentives. This argument moves to explore the agriculture sector by moving domestic trade versus agriculture. The statement that the agriculture sector is not a crucial sector meaning that resources came from agriculture could be moving to another sector of the economy sector without affecting agricultural development significantly (Pearson et al, 1991; Edison, 2014).

Nerlove in Edison (2020) noted that producers' response to variations in lagged agriculture prices also input prices in regional and international food markets both in simple and sophisticated results in a food supply dynamics. The unsteady food supply is the reason for unstable food fluctuations and food insecurity in Indonesia. Food is secured when there is adequate access to food at all times. At the household level, adequate access to food occurs when food is not only available but affordable for healthy living at all times. Food security is thus defined as the actual output of soybean that meets a planned supply needed for healthy living. Consideration of right supporting such as price or non-price support is mostly to have an impact on best supply responsiveness, on the other hand, that has disincentives impact. Importantly, movement in own-food prices gets more benefit as producers are mostly to have yielded more of that condition at good prices, so it can be better off on long-term food security (Oktaviani and Asmarantaka, 2010). BPS (2018) studied that it is important to care problem in prices of food that is responsible for problems in real and yield supply expectation of food in economies mostly. Arranging in input and prices may decrease soybean yield and income, continuing to prepare a decrease in real output from output expectation. It can direct to a selection of an alternative business by smallholder producers among the next planting season.

According to Mose and Kuvyenhoven (2007) about modernizing agricultural traditionally argued that lack of ability to agricultural contribution to development has created some doctrine also political problems. The problem with that doctrines was producers have less response to economic values. A crucial problem was that does agriculture yield in bad producers' income usually move up 
through the best allocation of input in their agricultural sector? How can value-added on increasing agricultural yield be got by using the allocative efficiency of farming properly? (Guyomard et al, 2003).

Therefore incentive factors which have played an important role in succeeding in any agricultural improvement program nowadays usually happened. Some empirical researches in the year of 1960s (Behrman 1989, Choi and Helmerger 1993, Keeney, and Hertel. 2008; Edison, 2011) expressed a problem on producers reaction on economical stimuli also response on the allocation of input using time series also cross-sectional data analysis in some underdeveloped places.

The commodity of agriculture in Indonesia along fifty years or so can be seen as some improvement in the input market also output market then experienced some policy movement causing in some improvement in the condition of market incentives got by producers. Meanwhile, very small improvements had been commodity-specific/commodity-oriented, such there has been a lot of combination movement in the incentive sector (Edison, 2011).

Picture of soybean product has a crucial view on improvement in increasing agriculture contribution also the capacity expectation and industrial sector development which influenced by supply on agricultural input. From that point, it seems that there is some contribution of the soybean sector with industry also another sector of economic value, which creates labor value also valueadded in the economic sector (Yu et al. 2010). Research aims were to improve our knowledge of response specification also a prediction of supply response on agriculture than to create a tool of policy analysis on agriculture. The major issue of this study is, what level of adjustments is required by actual soybean supply to close up the planned supply needed for healthy living over time? Again, what speed of adjustment is needed to establish a long-run equilibrium for steady-state food security? The issues have raised price oscillations and dynamism in equilibrium supply that initiated food shortages or surpluses and food insecurity (Edison and Wahyuni, 2020). The study is aimed at determining the level and speed of adjustments needed for actual soybean supply to meet the planned supply and arrest food insecurity in Indonesia, given the present input and commodity price policies in a changing climatic condition.

\section{LITERATURE REVIEW}

To grow food security, the agricultural commodity has played a crucial thing in supporting the food commodity sub-sector, also has an impact on economic development to stabilize the market condition. Food security is successful if humans generally get real also business access to enough, good, and hygiene food to fulfill their healthy food and preferences for a healthy life (FAO, 2006). Tollens (1998) explored three aspects of food security at household categories. They are; the existence of food, which states which food is sufficient for a healthy life. Food is available when there is enough production and supply is stable over time. Second is access and food utilization, prefer also enough and the best food for staying in good health. Accessibility food is accounted for by its market unit prices and cost of the food and value addition to the food. Finally, food must be affordable, implying that there should be enough household income to ensure adequate procurement of food that will sustain body requirements for an active and healthy life.

At the national and international levels, food security has meaning enough world food existence also enough power to fulfill food need words to receive or send, accept good food coming from countries of surplus food (Edison, 2020). In terms of delivery operation of "food security" is on linkage into micro also macroeconomics aspects. Edison (2014) stated the food security sector is the linkage point of macroeconomics also the regional part of the food market sector even-though it appeared that international agricultural impact on the food sector movement. This condition was drawn on individuals also aggregate food sector linkage, like the regional food sector will be linkage micro markets at the regional level. Development of agriculture and rural is connected to market stability, which actives when 
producers respond to enough production factors also food price policies that expressed the best food supply system, therefore the best food secured regime occurred. Meanwhile, Indonesia's local production of soybeans is on the upward regime but has continued to have a rapidly growing demand deficit and increasing market price since 2007. Indonesia Development Board (Bappenas, 2018) stated that increased lagged price conditions had bad conditions than increasing import also bad value-added regime, which changes to other food insecurity policies.

Function on the supply sector explains how much total production used for sale varies as its price varies to other prices of products (Cochrane, 1995; Nainggolan et al. 2018). Cochrane explores on supply response equations. Supply equation explains the quantity that would be supplied at changing prices with all other things constant, while the supply response relationship describes what will happen to the quantity supplied when all other things are not held constant (Askari and Cummings, 1977; Edison and Siata, 2017). Nerlove in Edison (2020) explored most of the operational framework in supply response articles.

Supposed supply equation is explained as

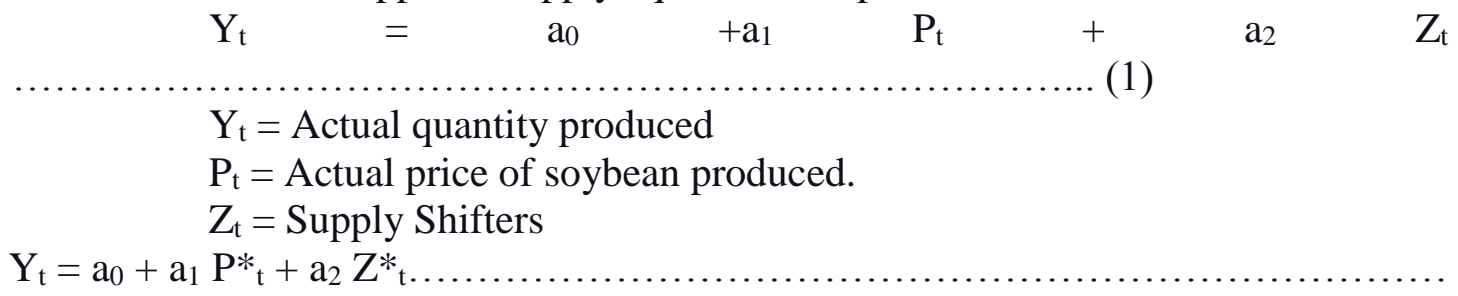

(2)
Where:
$\mathrm{Y}_{\mathrm{t}}=$ Quantity produced in time $\mathrm{t}$
$\mathrm{P} *_{\mathrm{t}}=$ Expected price
$Z^{*}{ }_{t}=$ Supply shifters expected

The expected price is not observable and is explained as expected ,normal ${ }^{\text {ee }}$ price, i.e., the level about which the future price is expected to fluctuate. This can be expected as:

$$
\begin{aligned}
& \text { Actual } \mathrm{P}-\mathrm{P}_{\mathrm{t}-1} \\
& \mathrm{P}^{*}-\mathrm{P}_{\mathrm{t}-1}=\beta\left(\mathrm{P}_{\mathrm{t}-1}-\mathrm{P}_{\mathrm{t}-1}\right),
\end{aligned}
$$
1

We assume the expected price is the actual price. $\mathrm{P}=\mathrm{P}^{*}$

We can get the following equation by getting the value of $\mathrm{P}^{*}$ from equation (2) and substituting in into equation (1) and rearranging it,

$$
\mathrm{Y}_{\mathrm{t}}=\mathrm{b}_{0}+\mathrm{b}_{1} \mathrm{P}_{\mathrm{t}-1}+\mathrm{b}_{2} \mathrm{Y}_{\mathrm{t}-1}+\mathrm{b}_{3} \mathrm{Z}_{\mathrm{t}-1}+\mathrm{b}_{4} \mathrm{Z}_{\mathrm{t}-1} \ldots \ldots
$$

The equation (3) can be estimated economically.

To estimate elasticities the formula used was $\partial \mathrm{Y} / \mathrm{P} . \mathrm{P} / \mathrm{Y}$ the first term for the short and long run will be: Short-run $\partial \mathrm{Y}_{\mathrm{t}} / \mathrm{P}_{\mathrm{t}-1}$ and Long run: $\mathrm{b}_{1} / 1-\mathrm{b}_{2}$

The planned or the desired (expected) output supply of soybean $\left(\mathrm{Y}_{\mathrm{d}}\right)$ in a year $(\mathrm{t})$ is a distributed lagged model that is explicitly expressed in Nerlovian sense as:

$$
\mathrm{Y}_{\mathrm{d}}=\mathrm{p}_{\mathrm{O}}+\mathrm{p}_{1} \mathrm{P}_{\mathrm{t}-1}+\mathrm{p}_{2} \mathrm{ExpP}_{\mathrm{t}-1}+\mathrm{p}_{3} \mathrm{EXP}_{\mathrm{vol}}+\mathrm{p}_{4} \mathrm{R}_{\mathrm{t}}+\mathrm{p}_{5} \mathrm{~A}_{\mathrm{t}}+\mathrm{s}_{\mathrm{t}}
$$

Where;

$\mathrm{Y}_{\mathrm{d}} \quad=$ the desired (expected) quantity of soybean supplied in kilogram in a year(t)Pt-1 is expected unit domestic price in a year(t) based on the previous expectations measured in naira 
$\operatorname{ExpP}_{\mathrm{t}-1}=$ the expected export price of soybean-based on previous expectations in

naira

$\mathrm{EXP}_{\mathrm{vol}}=$ the volume of export in a ton

$\mathrm{A}_{\mathrm{t}} \quad=$ the average area of land with soybean cultivation in a year $(\mathrm{t})$, measured in hectares

$\mathrm{R}_{\mathrm{t}} \quad=$ the volume of rainfall in a year $(\mathrm{t})$ measured in millimeters

$\mathrm{p}_{\mathrm{s}}^{\prime} \quad=$ vectors to be estimated in the equation.

Nerlovian model in equation (5) explores the expected price also appropriate factors of yield supply of soybean. This model is crucial in movement along with real and expected level yield supply. The movement was because of producers' response to the price level of production factor, policy consideration, response to yield price, production and value risk, season movement also variations in acreage factors. Meanwhile, all movements are explored in the Nerlovian adaptive expectations model because of yield movement along with beginning in proportion to the gap between real output supply in the current period and real output supply in the previous period which can generate dynamical food insecurity problem if best supply adjustment is got in the long-run. Therefore, a distributed lagged model creates an autoregressive (dynamic) model (Edison, 2020). The Nerlove adjustment model for soybean supply is thus presented as:

$$
\mathrm{Y}_{\mathrm{t}}-\mathrm{Y}_{\mathrm{t}-1} \quad=\quad \partial\left\{\mathrm{Y}_{\mathrm{d}}-\mathrm{Y}_{\mathrm{t}-1}\right\}
$$

Note: $\mathrm{Y}_{\mathrm{t}}$ is real supply in a year( $(\mathrm{t}), \mathrm{Y}_{\mathrm{t}-1}$ is previous output supply, $\mathrm{Y}_{\mathrm{t}}-\mathrm{Y}_{\mathrm{t}-1}$ translate to change in yield supply of soybean, and $Y_{d}$ is already stated in equation (5). The model substitution will show real yield supply in a year(t) as

$$
\mathrm{Y}_{\mathrm{t}}-\mathrm{Y}_{\mathrm{t}-1}=ð\left\{\mathrm{p}_{\mathrm{o}}+\mathrm{p}_{1} \mathrm{P}_{\mathrm{t}-1}+\mathrm{p}_{2} \operatorname{ExpP}_{\mathrm{t}-1}+\mathrm{p}_{3} \operatorname{Exp}_{\mathrm{vol}}+\mathrm{p}_{4} \mathrm{R}_{\mathrm{t}}+\mathrm{p}_{5} \mathrm{~A}_{\mathrm{t}}+\mathrm{S}_{\mathrm{t}}-\mathrm{Y}_{\mathrm{t}-1}\right\}
$$

Then equation (7) can be explored more as

$1+\partial \mathrm{S}_{\mathrm{t}} \ldots \ldots . .(8)$

$$
\mathrm{Y}_{\mathrm{t}}=ð \mathrm{p}_{\mathrm{o}}+ð \mathrm{p}_{1} \mathrm{P}_{\mathrm{t}-1}+ð \mathrm{p}_{2} \operatorname{ExpP}_{\mathrm{t}-1}+ð \mathrm{p}_{3} \operatorname{Exp}_{\mathrm{vol}}+ð \mathrm{p}_{4} \mathrm{R}_{\mathrm{t}}+ð \mathrm{p}_{5} \mathrm{~A}_{\mathrm{t}}+(1-ð) \mathrm{Y}_{\mathrm{t}-}
$$

The real yield supply of soybean in the Nerlovian model covers producers' response to some components like the season, acreage under soybean land, beginner supply also expected price from previous experience.

\section{RESEARCH METHOD}

\section{Analytical Procedure and Model Specification}

Trends in agricultural supply follow food real local supply as a proxy. This is described using relative mean values and ratios. The ratio of a change in mean supply relative to the previous mean supply multiplied by 100 gives the percentage in mean supply. Again, the ratio of soybean supply to total agricultural supply represents the soybean supply index. Time series data from 1986 to 2019 was chosen for this research. The problems considered in food supply response are preferred expectation price adjustment or partial yield adjustment as explored in a model $(5-7)$ above. The gap between the planned and actual soybean supply in Indonesia created a time-lapse that can be explained by the Nerlove adjustment model (Edison and Siata, 2017).

Model (8) is suitable in the Cobb-Douglas Function to find a technical relationship. The use of the Cobb-Douglas function has found supply elasticities because the parameter estimates of the Cobb-Douglas function are elasticities. Then, it is hoped a priori that all variables should have a direct effect on soybean yield supply response within the period the 
study reviewed. Therefore the following parameters and their representatives were possible from equation (5):

ð $\mathrm{p}_{\mathrm{O}}=\mathrm{A}, ð \mathrm{p}_{1}=\mathrm{B}, ð \mathrm{p}_{2}=\mathrm{C}$, б $\mathrm{p}_{3}=\mathrm{D}, \partial \mathrm{p}_{4}=\mathrm{E}, \partial \mathrm{p}_{5}=\mathrm{F}$ and $(1-ð)=\mathrm{G}$

If $(1-ð)=G$ then $\partial=1-G$. The final Nerlove estimation is:

ð $\mathrm{S}_{\mathrm{t}}$

$\ln Y_{t}=\ln A+B \ln P_{t-1}+C \ln E x p_{t-1}+D \ln E x p_{v o l}+E_{\ln R}+F \ln A_{t}+G \ln Y_{t-1}+$

The short supply elasticity could be generated directly from parameter (B) in equation 5.0, while the long-run adjustment in the elasticity of supply as used by Edison and Wahyuni, (2020) is expressed as:

Longrun Supply Elasticity\{LREq\} Short-run Supply Elasticity $\mathrm{H}_{0}$ as against $\mathrm{H}_{1}: \mathrm{n}<$ 0 and it is based on the $t$ - statistics of the coefficient $n$ from an OLS estimation of equation 7.0 above. This is followed by the cointegration modeling. Cointegration is a concept for modeling equilibrium or long-run relations of economic variables (Dickey and Fuller, 1981). Establishing a long-run supply response of soybean is built around the investigation of the number of cointegration relations, estimate their parameters, and place appropriate restrictions. This is finally followed by designing the complete model, assessing the quality of the model by adjusting the error mechanism for further investigation, and or forecasting.

\section{RESULTS AND DISCUSSION}

\section{The unit root test on the series}

Table 1 is the unit root test of all the series included in the model. The Augmented Dickey-Fuller (unit root) test was performed on the series as shown in Table 3. The stationarity test on the series was done at their level 1(0) and first difference 1(1) with their corresponding leg lengths in parenthesis. The null hypothesis of no presence of unit root cannot be rejected for the series in their level 1(0) as shown in Table 3 as the ADF of all the series were lower than the critical value of $(q-0.01)-3.558$ but were higher than the value when differenced by 1(1). This means that the alternative hypothesis is accepted that the series are stationary at first difference 11(1). The unit expected domestic prices, export price, the volume of export, present mean rainfall, and area under soybean cultivation each had a unit root at 1(1) see Table 1. It could be deduced from this finding that there could be a shortrun divergence and long-run relationship with the series, given the non- stationary properties at their levels and the lag length after differencing. The implication of non- stationarity or random-walk behavior in the variables highlighted stochastic trend behavior. Hence, a spurious estimation is imminent if a technical relationship is carried out at their level 1(0) with the series. Such stochastic error generated in the series is invariant with time (Edison, 2020). Therefore, error correction representation of the relationship is very imminent.

\section{Testing for co-integrating vectors}

It could also be seen from the result in Table 2 that the Trace statistics performed better than the Max-Eigen statistics at $(q=0.05)$. There is evidence of non-stationarity of the series due to their random walk behavior of unit root. A further test of co-integration with the Trace statistics is imperative. The cointegrating modeling brought the equations back to stationarity through a linear transformation [8]. The Max-Eigen value in Table 2. showed no cointegrating vector at $(\mathrm{q}=0.05)$ but the Trace Statistics indicated 2 cointegrating.

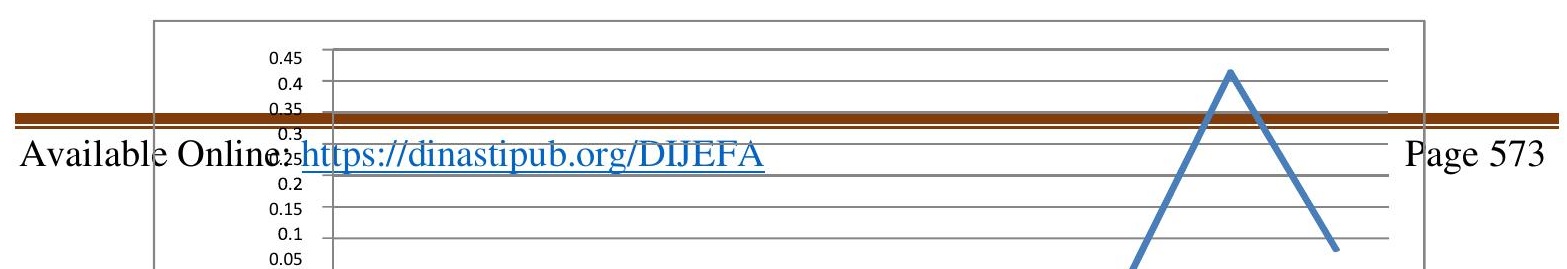




$\begin{array}{lllllllll}1986 & 1990 & 1994 & 1999 & 2003 & 2007 & 2011 & 2015 & 2019\end{array}$

Fig. 2. Trend in Soybean Contribution to Total Agricultural GDP from 1986 to 2019

Table 1. Stationarity (Unit root) test

\begin{tabular}{|c|c|c|c|c|}
\hline \multirow[t]{2}{*}{ Variable } & \multicolumn{3}{|c|}{ At level form } & At 1st \\
\hline & $\begin{array}{l}\text { ADF(lag } \\
\text { length) }\end{array}$ & Remark & $\begin{array}{l}\text { ADF(lag } \\
\text { lenght) }\end{array}$ & $\begin{array}{l}\text { Rema } \\
\text { rk }\end{array}$ \\
\hline Domestic price & $\begin{array}{l}-1.7622 \\
(2)\end{array}$ & $\begin{array}{l}\text { Non } \\
\text { Stationary }\end{array}$ & $-7.1844(1)$ & $\begin{array}{l}\text { Statio } \\
\text { nary }\end{array}$ \\
\hline Export price & $-0.7475(3)$ & $\begin{array}{l}\text { Non } \\
\text { Stationary }\end{array}$ & $-8.7927(2)$ & $\begin{array}{l}\text { Statio } \\
\text { nary }\end{array}$ \\
\hline Export volume & $-1.6476(1)$ & $\begin{array}{l}\text { Non } \\
\text { stationary }\end{array}$ & $-9.8326(1)$ & $\begin{array}{l}\text { Statio } \\
\text { nary }\end{array}$ \\
\hline Mean rainfall & $-2.3012(2)$ & $\begin{array}{l}\text { Non } \\
\text { Stationary }\end{array}$ & $-5.9564(2)$ & $\begin{array}{l}\text { Statio } \\
\text { nary }\end{array}$ \\
\hline Mean acreage & $\begin{array}{l}-1.7444 \\
(2)\end{array}$ & $\begin{array}{l}\text { Non } \\
\text { Stationary }\end{array}$ & $-6.3672(1)$ & $\begin{array}{l}\text { Statio } \\
\text { nary }\end{array}$ \\
\hline Previous output & $-0.5425(2)$ & $\begin{array}{l}\text { Non } \\
\text { Stationary }\end{array}$ & $-5.2645(2)$ & $\begin{array}{l}\text { Statio } \\
\text { nary }\end{array}$ \\
\hline
\end{tabular}

difference

Source: Result print out from E-view software, 2012. $(\mathrm{q}=0.01)$ are -3.558 and -3.592 vector (equation) at $\mathrm{q}=0.05$. The Trace statistics of 79.84 is greater than the critical value $(q=0.05)$ of 69.82 for at least two (2) cointegrating equations. The existence of at least one co-integrating equation/vector as shown by the Trace statistics indicated that there is an evidence of a long-run convergence or equilibrium despite the divergence of the series in the short-run (Greene, 2003).

Determinants of Soybean Supply and Error Correction Mechanism (ECM)

The maximum likelihood estimation of equation 5 revealed the determinant of 
soybean output supply in Nigeria. The result showed the effect of the included variables on soybean output supply and other functional parameters. The log likelihood ratio, Coefficient of Multiple Determinant (CMD) and Durbin-Watson statistic are 11.79, 0.229 and 1.846 respectively. It could be deduced from this finding that $22.9 \%$ variations in soybean output supply could be explained by the variations in the included explanatory variables such as the expected domestic prices, export prices, volume of export etc. The model does not have autocorrelation with a Durbin-Watson value of 1.85. An error correction vector $(\mathrm{ECM})$ of -0.344 , which is negative and statistically significant at $\mathrm{q}=$ 0.05 was obtained. The ECM of this model indicates that more than $34.4 \%$ adjustment towards long-run equilibrium for soybean output supplies is completed in one period. The speed of the short-run divergence, converges to equilibrium in the long-run with about $34.4 \%$ proportion of the disequilibrium in the soybean supply in less than one period being corrected in the next period.

Furthermore, it is revealed in this result that all the variables have direct effect on farmers output supply response except lagged export volume. This implies that apart from expected volume of export, other variables showed consistent behavior with $a$ priori expectation. The result show that the lagged value of yield has about $0.11 \%$ increase on the current output supply of soybean, implying that actual yield in the present year is sluggishly responding positively to last year's yield in the economy. Though the food self-sufficiency policy regime of the country has direct effect on supply responsiveness as farmers adjust with output supply to increase their supply following what happened in their previous supply, it may drag too long to meet the planned supply. The issue of meeting the demand deficit of $36.3 \%$ as noted by (BPS, 2018) due to sluggish inelastic supply nature of this product can simply be averted by massive support in production by the small holder farmers in Indonesia. Similarly, in unit lagged domestic price of soybean by $1.0 \%$ changing will create to move up $0.01 \%$ response in yield supplied. This represents that supply responsiveness is mainly affected on best domestic price expectation, therefore, food security with respect to soybean supply responsiveness is on best domestic price expectation. The same finding was got using expected export prices. There is a main best supply response of $0.028 \%$ with move up lagged export price compare to a unit increase in export volume. An increase in lagged export volume will force down soybean supply response by $0.022 \%$.

$$
\begin{aligned}
& \ln \mathrm{Q}_{\mathrm{t}}=0.042+0.010 \ln \mathrm{P}_{\mathrm{t}-1}+0.028 \ln \operatorname{Exp}_{\mathrm{t}-1}-0.022 \ln \operatorname{Exp}_{\mathrm{vol}}+0.093 \ln R_{\mathrm{t}}+ \\
& 0.018 \ln \mathrm{A}_{\mathrm{t}}+0.112 \ln \mathrm{Q}_{\mathrm{t}} \\
& (0.018)^{* *}(0.004)^{* *} \quad(0.019) \\
& (0.036)^{* * *} \\
& (0.011)^{* *} \text {. } \\
& (0.013)^{* * *} \cdot(0.022) \\
& \mathrm{ECM} \quad=-0.344 * * * \text { : } \\
& \text { Log likelihood ratio }=-11.79 \text { : } \\
& \mathrm{R}^{2} \\
& =0.230 \text { : } \\
& \begin{array}{ll}
\text { Adj } \mathrm{R}^{2} & =0.201: \\
\text { Durbin }- \text { Watson } & =1.846
\end{array}
\end{aligned}
$$

The study showed best explanation in price policies on soybean productivity in Indonesia. Soybean price policy era in Indonesia tends to support productivity increasing component obeying on international market movement mainly on external demand and domestic demand. The contrary relationship of export volume also inelastic nature soybean supply with the planned supply may be the reasons for the increased market 
prices. There may have been a lower than proportionate increase in expected output. Soybean farmers strived for increased food security with ignorance of inelastic supply nature and prices on their revenue. Policy era which explored farmers' resources use has to be done with caution so that output will expand massively at a lower input cost. Hence a look at input efficiency is suggested in this study. On the contrary, to get a good performance has to be way of best international market. Because price affects supply, treatment has to be create at regional yield stage to link targeted global demand also standard at a bigger price. Moreover, the average rainfall also expected place under soybean plantation will move up real supply of soybean. Even-though, this opposite with Edison and Wahyuni (2020) result, extended growth of soybean in the village (with short rainfall duration) needs an other source of water like irrigation to diverse its production to other place also maintain another season production.

\section{Elasticity, Soybean Supply Response and Food Security Prediction}

From estimation, it found that coefficient of adjustment was 0.794. It has meaning that positive value in short run estimation indicated its expected yield supply tended to positive. So that increasing in real supply was never coming quickly however, producers were usually active to make an expected output supply to real supply value in short-run adjustments.

In the very short-run, however, this situation seemed that expected price on domestic also export were all inelastic. Every changing expected price on domestic also export by $1.0 \%$ has impact on increasing proportionately real output of $0.017 \%$ and $0.034 \%$ respectively. This results explained evaluation that Indonesia regional yield of soybeans was staying in upward trend but still did not connect quickly improving demand. This increased food insecurity status as this demand deficit has affected price of soybean meal to double in 2012. These condition of high prices had big impacted on increasing import of soybean yield. The same effect is observed on rainfall and acreage with $0.089 \%$ and $0.024 \%$ increase in actual output respectively in the short-run. It is only export volume that is negative but still inelastic.

Table 2. Unrestricted co-integration rank test (Trace and maximum-eigenvalues)

\begin{tabular}{|c|c|c|c|c|c|}
\hline $\begin{array}{l}\text { Hypothesi } \\
\text { zed } \\
\text { (No. Of } \\
\text { CE(s)) }\end{array}$ & $\begin{array}{l}\text { Eigenval } \\
\text { ue }\end{array}$ & $\begin{array}{l}\text { Trace } \\
\text { statis } \\
\text { tics }\end{array}$ & $\begin{array}{l}\text { Critic } \\
\text { al } \\
\text { Value } \\
(\mathrm{q}= \\
0.05)\end{array}$ & $\begin{array}{l}\text { Max- } \\
\text { Eigen } \\
\text { statisti } \\
\text { cs }\end{array}$ & 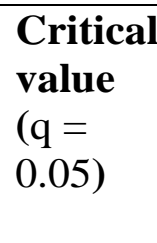 \\
\hline None* & 0.5487 & $\begin{array}{l}114.0 \\
6 * *\end{array}$ & 95.75 & 34.22 & 40.08 \\
\hline $\begin{array}{l}\text { At Most } \\
1 *\end{array}$ & 0.5273 & $\begin{array}{l}79.84 \\
* *\end{array}$ & 69.82 & 32.22 & 33.88 \\
\hline $\begin{array}{l}\text { At Most } \\
2 *\end{array}$ & 0.5157 & 47.62 & 47.86 & 31.18 & 27.58 \\
\hline At Most 3 & 0.2155 & 16.65 & 29.80 & 10.43 & 21.13 \\
\hline At Most 4 & 0.1305 & 6.01 & 15.49 & 6.01 & 14.26 \\
\hline At Most 5 & ${ }_{8}^{9.33 \times 10^{-}}$ & $\begin{array}{l}4.01 \mathrm{X} \\
10^{-6}\end{array}$ & 3.84 & $\begin{array}{l}4.01 \times 1 \\
0^{-6}\end{array}$ & 3.84 \\
\hline
\end{tabular}


Table 3. Short and long-run elasticity of soybean supply in Indonesia

\begin{tabular}{llll}
\hline Variables & $\begin{array}{l}\text { Short-run } \\
\text { elasticities }\end{array}$ & $\begin{array}{l}\text { Co-efficient of } \\
\text { adjustment }\end{array}$ & $\begin{array}{l}\text { Long- } \\
\text { run } \\
\text { elasti } \\
\text { cities }\end{array}$ \\
\hline $\begin{array}{l}\text { Expected domestic } \\
\text { price }\end{array}$ & 0.017 & & 0.011 \\
$\begin{array}{l}\text { Expected export price } \\
\text { Expected volume }\end{array}$ & 0.034 & & 0.032 \\
exported & -0.036 & & -0.025 \\
Rainfall & 0.089 & 0.794 & 0.106 \\
Acreage & 0.024 & & 0.020 \\
Previous output supply & 0.112 & & 0.126 \\
\hline
\end{tabular}

From estimation, it just few improvement explored using all parameters inelastic in long-run. This result was consistent as (Edison and Wahyuni, 2020). Characteristics in short-run had contribution in long-run also revision was hoped with producers model of adjustment. Therefore, better proportional improvement in real product is going to make producers react to price food policy era.

Table 4. Structural co-efficient, their significance and value of $\mathbf{R}^{2}$ for soybean production response in Indonesia

\begin{tabular}{|c|c|c|c|c|}
\hline Variable & $\begin{array}{l}\text { Co- } \\
\text { efficie } \\
\text { nt }\end{array}$ & $\begin{array}{l}\text { Standar } \\
\text { d Error }\end{array}$ & $\begin{array}{l}\text { t- } \\
\text { Rati } \\
\text { o }\end{array}$ & $\begin{array}{l}\text { Significan } \\
\text { ce }\end{array}$ \\
\hline $\begin{array}{l}\text { Consta } \\
\text { nt }\end{array}$ & 6,82 & 0.867 & & \\
\hline $\mathrm{PR}_{\mathrm{t}-1}$ & 0.372 & 0.067 & $\begin{array}{l}5.55 \\
2\end{array}$ & $* * *$ \\
\hline $\mathrm{YR}_{\mathrm{t}-1}$ & 0.608 & 0.146 & $\begin{array}{l}4.16 \\
4\end{array}$ & $* * *$ \\
\hline Dt & -0.319 & 0.112 & $\begin{array}{l}2.84 \\
8\end{array}$ & $* *$ \\
\hline $\begin{array}{l}\mathrm{R}^{2} \\
\mathrm{R}^{2} \text { (Adjusted) }\end{array}$ & $\begin{array}{l}0.9167 \\
0.8792\end{array}$ & & & \\
\hline
\end{tabular}

*** = Significant at 1 percent level of Significance.

** = Significant at 5 percent level of Significance

Evaluation determination co-efficient determination on yield response model showed that $88 \%$ dynamic Indonesia soybean yield is presented by internal factors existed in equation. Soybean lagged price coefficient had positive value with coefficient of 0.372 . The value was significant at $\alpha 1 \%$ also showed that when soybean price changed one unit in last year, it has impact on production of 0.372 units. Value and magnitude of coefficient got as expected. Then coefficient of production factor had a positive value with a number of 0.608 and was significant at $\alpha 1 \%$ also that explained lag production showed a good impact on soybean yield. Magnitude and value of coefficient was as expected. Furthermore, dummy 
factor showed government era before in 1998. Value coefficient showed negative, like it was hoped and number of 0,319 also was significance at $\alpha 5 \%$. Negative effect of government era in yield sector seemed because of non-existing inputs at important step in production process.

\section{CONCLUSIONS}

There is very important exploring food need by minimizing gap between planned supply and actual quantity supplied of soybean. It is proof of short-run dynamic supply inside also outside price inelasticity in which supported in the long run. So that, self sufficiency framework the present transformation agenda of the federal government should not target only productivity growth but also an elastic actual output in an efficient input use. This will contribute better proportion improvement in soybean response needed to explore food in Indonesia.

The study therefore, stated an elastic soybean output at reduced market prices. It is suggested that an efficient and cost-effective input use as well as expanded acreage with irrigation (that will contribute quick rainfall season) was inserted in policy model in transformation agender of the federal government. It will initiate an output response that invigorates both domestic and export supply at a reduced domestic price. Expensive local price can cause down export also it requires immediate improvement. Such improvement comes if it was investigation deeply on input use efficiency. A close look at input efficiency will suggest the cost effective production system that can increase output at a reduced cost, hence reduced market prices. Again, useful of input use efficiently will improve producers benefits also output so that farmers will have more incentive to produce and export will be increasing. Other use of soybean also value added to yield can create better unit price, that can change to improved yield, benefits also then supply yield response.

\section{REFERENCES}

1. Askari H. and Cummings J.T. Estimating Agricultural Supply Response with the Nerlove Model. International Economic Review. 1977 18(2): 257-92.

2. Bappeda. Raw Material and Research Development Annual Survey Report. Raw Material Research and Development Council of Indonesia. Jakarta. 2018.

3. Bapna, S.L., Binswanger, H.P. and Quizon, J.B. Systems of Output Supply and Factor Demand for Semiarid Tropical India. Economic Growth Centre, Yale University USA. Pp. 179 - 202, 1991.

4. Behrman J. R. Supply Response in Underdeveloped Agriculture. Amsterdam. North Holland. 1989.

5. BPS, National Population Commission. National Population Cencius Figures and Analysis. National Population Commission Indonesia, Jakarta. 2018.

6. Carpentier, A.: Gohin, A.: Schokai, P. and Thomas. A. Economic Modelling of Agricultural Production: Past Advances and New Challenges. Review of Agricultural and Environmental Studies. 2015 96(1): 131-165.

7. Choi, J.S. and Helmerger P.G. How Sensitive are Crop Yield to Price Changes and Farm Programs? Journal Agriculture and Applied Economics. 1993 25:237-244

8. Cocharne, W.W. Conceptualizing the Supply Relation in Agriculture. Journal of Economics, 1995 37(5): 1161-75.

9. Colin, T and Townsend R. Dynamic Supply Response Estimation. Annual Conference of AARES. Melbourne Australia. 2011.

10. Dickey DH, and Fuller WH. Likelihood Ratio Statistics for Autoregressive Time Series with Unit Root. Econometrics 1981 49(4): 1057-1072.

11.Edison, The Responsiveness of Jambi Rice Acreage to Price and Production Costs. 
Proceeding International Seminar CRISU-CUPT in Unsri, Palembang. 2011.

12.Edison, The Responsiveness of Rice Area to Price and Production Cost in Jambi. International Journal of Agricultural System. 20142 (2): 133-139..

13. Edison and R. Siata, The Analysis of Soybean Production Supply Response in Tebo District, Jambi. Proceeding National Seminar BKS-PTN in Babel University. Bangka. Pp. 46 - 53. 2017.

14.Edison, The Effect of Price on Meta Profit Function Model: A Case of Western Indonesia Soybean, International Journal of Management Studies, 2020 7(1): 20-25.

15.Edison and Wahyuni,I. Acreage Response under Price Policy Program on Corn Production, International Journal of Scientific \& Technology Research , 2020 9,3, 345 $-349$

16. Engle RF, and Granger CWJ. Co-integration and Error Correction Representation, Estimating and Testing. Econometrics 2010. 55:251-276.

17. Food and Agricultural Organization. Production Year Book. FAO, Rome, Italy. 2015.

18. Fuller WA. Introduction to Statistical Time Series. Willey, New York. (USA). 1995.

19. Goodwin, B.K.; Ramsey, A.F.: and Chvosta, J. Applied Econometrics with SAS: Modelling Demand, Supply and Risk. SAS Institute Inc. Cary, NC. USA. Pp. 1 - 74, 2018.

20. Greene W. Econometric Analysis Prentice Hall New Jessey, (USA). 2018.

21.D.N. Gujarati, and D.C. Porter, Basic Econometrics. International Edition ( $5^{\text {th }}$ edition) McGraw-Hill New York. Pp. 1 - 900, 2009.

22. Guyomard, H.; Baudry, M. and Carpenter, A. Estimating Crop Supply Response in the Presence of Farm Programmes: Application to the CAP. European Review of Agricultural Economics 2003 23:401-420.

23. Johnson S. Statistical Analysis of Co-integration Vectors. Journal of Economic Dynamics and Control 1988 12:231-234.

24. Keeney, R. and T.W. Hertel. Yield response to prices: implications for policy modeling. Working Paper Dept. of Agricultural Economics Purdue University. Pp. 136. 2008.

25. Mose, L.B.K and Kuvyenhoven, A. Aggregate Supply Response to Price Incentives: The Case of Smallholder Maize Production in Kenya', African Crop Science Conference Proceedings, 2007 8(1):1271-1275.

26. Nainggolan, S., Murdy, S. and Malik, A. Kajian Pendugaan Fungsi Produksi Usahatani Padi Sawah di Kabupaten Muaro Jambi Provinsi Jambi. Fakultas Pertanian Universitas Jambi, Jurnal Penelitian Pertanian, 2018 1(1), 71-86.

27. Oktaviani R, Asmarantaka RW. The Rise in International Food Prices: The Impact on and Policy Implications for Indonesian Food Security. Department of Economics and Agribusiness, Faculty of Economics and Management, Bogor Agricultural University, Indonesia. Contributed Paper at the Thirteen Annual Conference on Global Economic Analysis United Nations Conference Centre, Bangkok, Thailand. 2017.

28. Pearson, S. Falcon, W. Heytens, P. Monke, E and Naylor, R. Rice Policy in Indonesia, Cornell University Press. Ithaca New York. 1991.

29. Savadatti, P.M.; Supply Response of Pigeonpea in India, Cointegration and Vector Error Correction Analysis, International Journal of Research in Economics and Social Sciences (IJRESS), 2018 8(2): 381-392 
30. Tollens E. Food security: Incidence and causes of insecurity among vulnerable groups and coping strategies. In: Food security in ACP countries, Proceedings of a CTA seminar, Leuven, Belgium. 1998.

31. Tripath A. Estimation of Agricultural Supply Response by Co-integration Approach. Indian Crauh Institute of Development Research. India. 2017.

32. United State's Development Agency. USDA. Indonesian Soybean Output Growing. Trade Intelligence Alibaba.com, America. 2018.

33. Yu, B. Liu, F, and You, L. (Dynamic Agricultural Supply Response Under Economic Transformation. IFPRI Discussion Paper, Washington, D.C. U.S.A. 2010. 